\title{
Global Financial Crises and Its Impact on India
}

\author{
Manjushri Abhishek Kadam
}

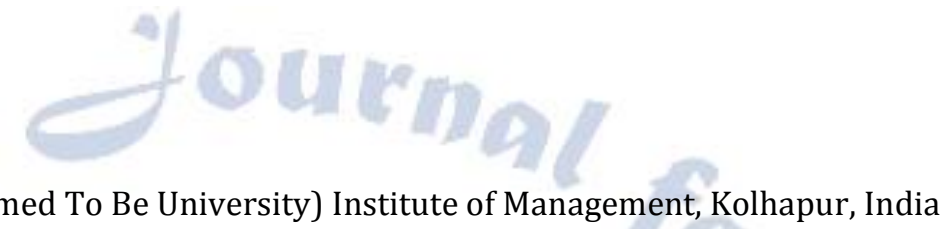

Assistant Professor, Bharati Vidyapeeth (Deemed To Be University) Institute of Management, Kolhapur, India

To Cite this Article

Manjushri Abhishek Kadam, "Global Financial Crises and Its Impact on India", International Journal for Modern Trends in Science and Technology, Vol. 07, Issue 01, January 2021, pp.- 107-110.

\section{Article Info}

Received on 18-December-2020, Revised on 02-January-2021, Accepted on 08-January-2021, Published on 14-January-2021.

\section{ABSTRACT}

Indian economy is experiencing a downturn after a long spell of growth. Industrial growth is faltering, the current account deficit is widening, foreign exchange reserves are depleting and the rupee is depreciating because of financial crises. The crises originated in United States but the Indian Government has a reason to worry because there is a potential adverse impact of the crises on India. The global economic slowdown is unprecedented in scale and has severe implications on policy formulation among emerging market. Currently India has one of the largest Developing countries in the world. Strong economic growth in the last decade combined with a population of over a billion makes it one of the potentially largest markets in the future. This paper provides an overview of global financial crisis (GFC) and its impact on the Indian Economy.

\section{Keyword: Financial Crises}

\section{INTRODUCTION}

The global financial crisis is an outcome of deep economic recession which generally refers to business cycle contraction and slowdown activity over a long period of time. It is a situation where macro indicator like gross domestic product, employment, capital utilization, household incomes and business profit fall and bankruptcies and unemployment rates are rise. Global Financial Crisis is among the greatest financial challenges to the world economy which is originated in United States of America. The global economic slowdown is unprecedented in scale and has severe implications on policy formulation among emerging market. Currently India has one of the largest Developing countries in the world. Strong economic growth in the last decade combined with a population of over a billion makes it one of the potentially largest markets in the future.

The current global economic slowdown has its epicentre in the United States (US) but the contagion is being witnessed in all major economies of the world. India's economy has been fuelled by the growth in the technology sector in the recent past. A large part of this growth is dependent on the "outsourcing" or "off shoring" of key business processes and software development activity (and related services) by large global corporations and other organizations. Hence, the global slowdown has also affected the business climate within India and the growth rate of the all industries. With the increasing integration of the Indian economy and its financial markets with rest of the world, there is recognition that the country does face some downside risks from these international developments. The risks arise mainly from the potential reversal of capital flows on a sustained medium term basis from the projected slow down of the global economy, particularly in advanced economies, and from some elements of potential financial contagion. In India, the adverse effects have so far been mainly in the equity 
markets because of reversal of portfolio equity flows, and the concomitant effects on the domestic forex market and liquidity conditions. The macro effects have so far been muted due to the overall strength of domestic demand, the healthy balance sheets of the Indian corporate sector and the predominant domestic financing of investment.

\section{CAUSES OF GLOBAL FINANCIAL CRISES}

The world economy is now more interconnected than ever. Financial markets are heavily regulated while capital markets are expanding in Asia, Africa and Latin America. The banking sector is going through a concentration process with fewer and fewer players left. Mexico, Indonesia, Nigeria and Turkey (the MINT countries) are coming into focus after Brazil, Russia, India, China and South Africa (the BRICS) have disappointed. Europe seems to be back in the game, with Germany leading the recovery of the continent. The US is still the world's most competitive economy, The process of deleveraging the balance sheets of governments and companies is under way. Interest rates and government bond yields are at historical lows and stock markets have recovered to pre-crisis levels.

The financial crises happened because banks were able to create too much money, too quickly and used it to push up house prices and speculate on financial markets.

\section{Banks created too much Money}

Every time a bank makes a loan, new money is created. In the run up to the financial crisis, banks created huge sums of new money by making loans. In just 7 years, they doubled the amount of money and debt in the economy

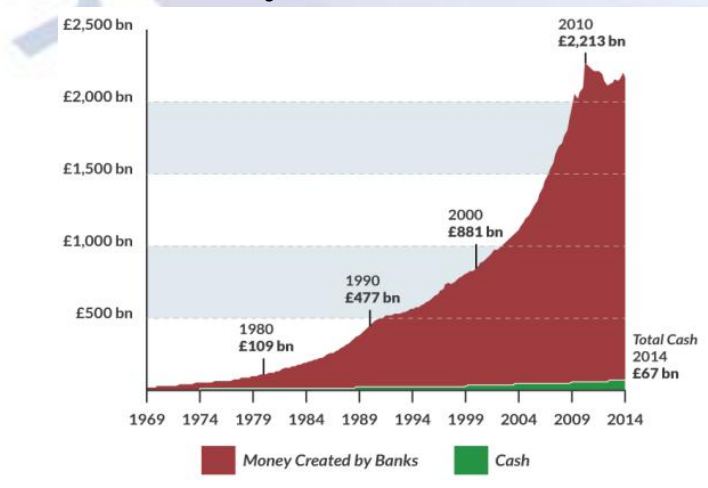

\section{Using this money to push up house prices and speculate on financial markets}

Very little of the trillion pounds that banks created between 2000-2007 went to businesses outside of the financial sector:

- Around $31 \%$ went to residential property, which pushed up house prices faster than wages.
- A further $20 \%$ went into commercial real estate (office buildings and other business property)

- Around $32 \%$ went to the financial sector, and the same financial markets that eventually imploded during the financial crisis.

- But just $8 \%$ of all the money that banks created in this time went to businesses outside the financial sector.

- A further $8 \%$ went into credit cards and personal loans.

\section{Eventually the debts became unpayable}

Lending large sums of money into the property market pushes up the price of houses along with the level of personal debt. Interest has to be paid on all the loans that banks make, and with the debt rising quicker than incomes, eventually some people become unable to keep up with repayments. At this point, they stop repaying their loans, and banks find themselves in danger of going bankrupt.

\section{Financial crises}

This process caused the financial crisis. Straight after the crisis, banks limited their new lending to businesses and households. The slowdown in lending caused prices in these markets to drop, and this means those that have borrowed too much to speculate on rising prices had to sell their assets in order to repay their loans. House prices dropped and the bubble burst. As a result, banks panicked and cut lending even further. A downward spiral thus begins and the economy tips into recession.

\section{After the crises, Bank refuses to lend and the economy Shrinks}

Banks lend when they're confident that they will be repaid. So when the economy is doing badly, banks prefer to limit their lending. However, although they reduce the amount of new loans they make, the public still have to keep up repayments on the debts they already have.

The problem is that when money is used to repay loans, that money is 'destroyed' and disappears from the economy. So when people repay loans faster than banks are making new loans, it's like draining the oil from the engine of a car: the economy slows down and prices decrease. As a result the economy risks slipping into a 'debt-deflation' spiral, where wages and prices fall but people's debts do not change in value, leading to debts becoming relatively more expensive in 'real' terms. Even those businesses and people that 
weren't involved in creating the bubble suffer, causing a recession.

\section{IMPACT ON INDIA}

\section{- IT Industry}

Indian IT companies are well accredited for its quality software and services, well stated to be a major employment opportunity creator. Since, India has abundant labor resources and plays a major service provider across the globe. Many foreign companies are attracted to the Indian IT companies for its software development and for its service outsourcings. The recent outsourcing boom into India from the foreign countries mainly from US left an impact in the in the IT industry, which is accounted to be a major player in employment and foreign exchange. Approximately $60 \%$ of the Indian IT sector's revenue is fully based only on the US suppliers. Around 30\% of the industry's revenue is generated from the financial services companies from US. Indian companies were appreciated for its flexibility in work, Quality product deliveries and for its efficient services. As there were no intense partnering between Indian firms and major financial services, major share of the IT firms were saved from the impact of the recession. Even though, some Indian IT companies partnered with US financial companies like Lehman Brothers Inc and Meryl Lynch Inc affected a little. This slowdown in the US economy lead $70 \%$ of the firms to negotiate for lower rates with their suppliers and nearly $60 \%$ have cut back the contracts. The sudden fall in the US economy reduced the growth of Indian IT firms down by $2-3 \%$.

\section{- Investment}

The tumbling economy in the U.S is going to dampen the investment flow. It is expected that the capital inflows into the country will dry up. Investments in mega projects, which are under implementation and in the pipeline, are bound to buy more time before injecting funds into infrastructure and other ventures. The buoyancy in the economy is absent in all the sectors. Investment in tourism, hospitality and healthcare has slowed down. Fresh investment flows into India is in doubt.

\section{- Real Estate}

One of the casualties of the crisis is the real estate. The crisis will hit the Indian real estate sector hard. The realty sector is witnessing a sudden slump in demand because of the global economic slowdown. The recession has forced the real estate players to curtail their expansion plans. Many on-going real estate projects are suffering due to lack of capital, both from buyers and bankers. Some realtors have already defaulted on delivery dates and commitments. The steel producers have decided to resort to production cuts following a decline in demand for the commodity.

\section{- Banks}

The ongoing crisis will have an adverse impact on some of the Indian banks. Some of the Indian banks have invested in derivatives which might have exposure to investment bankers in U.S.A. However, Indian banks in general, have very little exposure to the asset markets of the developed world. Effectively speaking, the Indian banks and financial institutions have not experienced the kind of losses and write-downs that banks and financial institutions in the Western world have faced. Indian banks have very few branches abroad. Our Indian banks are slightly better protected from the financial meltdown, largely because of the greater role of the nationalized banks even today and other controls on domestic finance. Strict regulation and conservative policies adopted by the Reserve Bank of India have ensured that banks in India are relatively insulated from the travails of their western counterparts.

\section{- Foreign Exchange Outflow}

After the macro-economic reforms in 1991, the Indian economy has been increasingly integrated with the global economy. The financial institutions in India are exposed to the world financial market. Foreign institutional investment (FII) is largely open to India's equity, debt markets and market for mutual funds. The most immediate effect of the crisis has been an outflow of foreign institutional investment from the equity market. There is a serious concern about the likely impact on the economy because of the heavy foreign exchange outflows in the wake of sustained selling by Foreign Institutional Investors in the stock markets and withdrawal of funds by others. The crisis resulted in net outflow of $\$ 10.1$ billion from the equity and debt markets in India. There is even the prospect of emergence of deficit in the balance of payments in the near future.

\section{- Exchange Rate}

Exchange rate volatility in India has increased in the year 2013-14 compared to previous years. Massive selling by Foreign Institutional Investors 
and conversion of their holdings from rupees to dollars for repatriation has resulted in the rupee depreciating sharply against the dollar. Since 2012 the RBI reference rate for rupee fell by nearly $25 \%$ from 53.22 per $\$$ to 63.10

\section{CONCLUSION}

The entire world economies are affected in one way or other by the financial crisis. The strength and duration of the impact do vary among the economies on the basis of the nature of their domestic economy. Indian economy too was not free from the hit of the current crises, Great savings habit among people, strong fundamentals, strong conservative and regulatory regime have saved Indian economy from going out of gear, though significant parts of the economy have slowed down and there is a wide variance of opinion about how long it will continue. It is expected that growth will be moderate in India. The most important lesson that we must learn from the crisis is that we must be self-reliant; we must adopt protectionist measures in certain sectors of the economy so that recession in any part of the globe does not affect our country.

\section{REFERENCES:}

[1] http://www.hindu.com/2011/01/13/stories/201101136 6962000

[2] http://www.rbi.org.in/scripts/BS_Speeches

[3] Financial Crisis and its Impact on Seleced IT Industries in India ( 2013)- C. THANGA LAKSHMI. DR. ISACC BALASINGH.

[4] Nirupam Bajpai (2010), 'Global financial crisis, its impact on India and the policy response.

[5] Viswanathan, K G (2010), 'the Global financial Crisis and its impact on India', The Journal of International Business and Law, Vol.9, pp.41-42,

[6] http://www.positivemoney.org/issues/recessions-crisis/ 